\title{
THE INFLUENCE OF DIET ON QUALITY NUTRITION COUNSELLING PATIENTS OF DIABETES MELLITUS TYPE II IN POLY DISEASE IN THE RSUD Dr.M. YUNUS BENGKULU YEAR 2018
}

\author{
Rossy Tri Pertiwi, Emy Yuliantin, Anang Wahyudi \\ Jurusan Gizi, Poltekkes Kemenkes Bengkulu, Jl. Indragiri No. 03, Kota Bengkulu, 38225 \\ Email : rossytripertiwi3@gmail.com
}

\begin{abstract}
Nutritional counseling is one of the efforts of the medical nutrition therapy provided to improve the diet and lifestyle of patients of diabetes mellitus.One of the key factors in the treatment of the disease of diabetes mellitus is an improvement of the quality of the diet.The purpose of this research is to know the influence of diet on quality nutrition counselling patients of diabetes mellitus in poly disease in the RSUD dr.M. Yunus Bengkulu year 2018. This type of research is pre-circling with pre and posttest one gorup design. This research was carried out from April to may 2018. The location of the research on poly disease in the RSUD dr.M. Yunus Bengkulu. research Sample is selected by purposive sampling in accordance with the criteria of inclusion and ekslusi.The number of samples that is 20 respondents. The data are tested using the kolmogorov smirnov test, wilcoxon. The results of the research there is a meaningful influence obtained between nutritional counseling to the quality of the patient's diet diabetes mellitus type II in Poly disease in the RSUD dr.M. Yunus Bengkulu Year 2018 with $(\mathrm{p}=0.006)$. Expected to further researchers can continue research on diabetes mellitus patients with more samples to make it more visible variations in the quality of diet of diabetes mellitus patients and researchers can then tried a more educational media varied to seek effectiveness in the media.
\end{abstract}

Keywords: Diabetes Mellitus, counseling, Diet quality

\section{PENGARUH KONSELING GIZI TERHADAP KUALITAS DIET PASIEN DIABETES MELITUS TYPE II DI POLI PENYAKIT DALAM RSUD dr. M.YUNUS BENGKULU TAHUN 2018}

\begin{abstract}
ABSTRAK
Konseling gizi merupakan salah satu upaya terapi gizi medis yang diberikan untuk memperbaiki pola makan dan gaya hidup pasien diabetes melitus. Salah satu faktor kunci dalam penatalaksanaan penyakit diabetes melitus adalah perbaikan kualitas diet. Tujuan penelitian ini untuk mengetahui pengaruh konseling gizi terhadap kualitas diet pasien diabetes melitus di poli penyakit dalam RSUD dr. M.Yunus Bengkulu tahun 2018. Jenis penelitian ini adalah pre experimen dengan rancangan pre dan posttest one gorup design. Penelitian ini dilaksanakan pada bulan April sampai bulan Mei 2018. Lokasi penelitian di poli penyakit dalam RSUD dr. M. Yunus Bengkulu. Sampel penelitian yang dipilih secara purposive sampling sesuai dengan kriteria inklusi dan ekslusi. Jumlah sampel yaitu 20 responden. Data diuji menggunakan kolmogorov smirnov, uji wilcoxon. Hasil penelitian ini didapatkan ada pengaruh yang bermakna antara konseling gizi terhadap kualitas diet pasien diabetes melitus type II di Poli penyakit dalam RSUD dr. M. Yunus Bengkulu Tahun 2018 dengan $(\mathrm{p}=0.006)$. Diharapkan kepada peneliti selanjutnya dapat melanjutkan penelitian pada pasien diabetes melitus dengan sampel yang lebih banyak agar lebih terlihat variasi kualitas diet pasien diabetes melitus dan peneliti selanjutnya dapat mencoba media edukasi yang lebih bervariasi untuk mencari efektivitas pada media tersebut.
\end{abstract}

Kata kunci: Diabetes Melitus, Konseling, Kualitas Diet 


\section{PENDAHULUAN}

Diabetes merupakan salah satu dari empat prioritas penyakit tidak menular, $80 \%$ kejadian diabetes dapat dicegah dengan tatalaksana pengobatan yang optimum dan dikontrol. Pada tahun 2015, 415 juta orang dewasa dengan diabetes kenaikan 4 kali lipat dari 108 juta tahun 1980 diperkirakan jumlahnya akan menjadi 647 juta pada tahun 2040. (1)

Pada tahun 2015, Indonesia menempati urutan ke tujuh dunia untuk prevalensi penderita diabetes melitus tertinggi diikuti dengan Negara China, India, Amerika Serikat, Brazil, Rusia, dan Meksiko dengan jumlah estimasi orang dengan diabetes sebesar 10 juta.(2) Menurut WHO sebanyak 171 juta orang menderita diabetes mewakili $2,8 \%$ dari populasi dunia, dan diprediksi bahwa jumlah ini akan meningkat 366 juta $(4,4 \%)$ pada tahun 2030. (1)

Berdasarkan hasil Riset Kesehatan Dasar, menunjukkan hasil wawancara terhadap responden diabetes melitus usia $\geq 15$ tahun di Indonesia, terjadi peningkatan jumlah persentase dari 1,1\% pada tahun 2007 menjadi $2,1 \%$ pada tahun 2013. Hasil analisis gambaran prevalensi DM berdasarkan jenis kelamin prevalensi pada wanita
$(1,7 \%)$ lebih besar dibandingkan pada laki-laki $(1,4 \%)$ sedangkan berdasarkan wilayahnya prevalensi DM diperkotaan (2\%) lebih besar dibandingkan perdesaan (1\%). Prevalensi DM yang di diagnosa dokter didaerah Bengkulu sebesar $0,9 \%$ menepati urutan 29 dari 33 provinsi di Indonesia, sedangkan Bengkulu berada di urutan ke-6 dari 10 provinsi yang ada di Sumatera. (3)

Salah satu upaya meningkatkan pengetahuan dan kemampuan individu atau keluarga tentang gizi dapat dilakukan melalui konseling. Konseling merupakan suatu bentuk pendekatan yang digunakan dalam asuhan gizi menolong individu dan keluarga memperoleh pengertian yang lebih baik tentang dirinya serta permasalahan yang dihadapi. Setelah melakukan konseling, diharapkan individu dan keluarga mampu mengambil langkah-langkah untuk mengatasi masalah gizinya termasuk perubahan pola makan serta memecahkan masalah terkait gizi kearah kebiasaan hidup sehat.(4)

Kualitas diet yang baik, akan membantu pasien mengontrol kadar gula darah dan menghindari berbagai komplikasi yang mungkin timbul akibat penyakit ini. Penelitian di Spanyol menunjukkan kualitas diet yang rendah 
pada pasien diabetes melitus dengan obesitas, sedangkan di Perancis melaporkan pasien diabetes mellitus mengalami kesulitan mencapai tingkat kepatuhan diet yang diinginkan. (5)

$$
\text { Healthy eating index (HEI) }
$$
merupakan salah satu alat yang dikembangkan oleh United State Department of Agriculture (USDA) untuk mengukur kualitas diet seseorang. Semakin besar nilai HEI seseorang, maka semakin baik kualitas dietnya. Gambaran perubahan kualitas diet pasien sebelum dan sesudah mendapat konseling gizi dapat menjadi salah satu indikator keberhasilan penatalaksanaan diet penyakit diabetes mellitus.(5)

Menurut penelitian mengatakan bahwa pengaruh konsultasi terhadap kadar gula darah sebelum dan sesudah konsultasi pada pasien Diabetes melitus didapatkan hasil ada pengaruh yang bermakna antara konsultasi gizi terhadap gula darah Diabetes melitus.(6) Perubahan kualitas diet kelompok kontrol berbeda signifikan dengan perubahan kualitas diet pada kelompok perlakuan. Konseling gizi individu dan kelompok terbukti memperbaiki kualitas diet pada pasien diabetes melitus.(5)
Menurut penelitian mengatakan bahwa ada peningkatan pengetahuan pasien diabetes mellitus atau responden mengenai diabetes mellitus sebelum intervensi dan sesudah intervensi dan Ada peningkatan sikap pasien diabetes mellitus atau responden mengenai diabetes mellitus sebelum intervensi dan sesudah intervensi dengan metode konseling gizi dengan media audiovisual di Rumah Sakit Islam Samarinda.(7)

Berdasarkan data profil jumlah pasien diabetes melitus poli penyakit dalam di RSUD dr.M.Yunus Bengkulu pada tahun 2016 jumlah pasien 493 sedangkan pada tahun 2017 jumlah pasien 1083 orang data dari unit rekam medik dan informasi RSUD dr. M.Yunus Bengkulu 2017. Hal ini menunjukan terjadi peningkatan pasien dari tahun 2016 sampai 2017 sehingga berdasarkan latar belakang diatas maka peneliti tertarik untuk meneliti pengaruh konseling gizi terhadap kualitas diet pasien diabetes melitus di RSUD dr. M.yunus Bengkulu.

\section{METODE PENELITIAN}

Penelitian ini menggunakan desain penelitian pre eksperimen. Dengan desain pre dan posttest one group design. Penelitian dilakukan di 
RSUD dr. M. Yunus Bengkulu.

Populasi dalam penelitian ini adalah pasien diabetes melitus type II, yang berkunjung ke poli penyakit dalam

Tabel 1. Karakteristik Responden

\begin{tabular}{lcc}
\hline \multicolumn{1}{c}{ Kategori } & n & \% \\
\hline Jenis Kelamin & & \\
Laki-Laki & 10 & 50 \\
Perempuan & 10 & 50 \\
Umur & & \\
36-45 Tahun & 2 & 10 \\
46-55 Tahun & 7 & 35 \\
56-65 Tahun & 8 & 40 \\
>65 Tahun & 3 & 15 \\
Pendidikan & & \\
Tidak Tamat Sekolah & 1 & 5 \\
SD & 3 & 15 \\
SMP & 4 & 20 \\
SMA & 5 & 25 \\
S1 & 7 & 35 \\
Pekerjaan & & \\
IRT & 7 & 35 \\
Wiraswasta & 5 & 25 \\
PNS & 5 & 25 \\
Pensiunan & 2 & 10 \\
Buruh & 1 & 5 \\
Indeks Massa Tubuh & & \\
Kurus berat (<17.0) & 2 & 10 \\
Kurus ringan (17.0-18.4) & 1 & 5 \\
Normal (18.5-25.0) & 11 & 55 \\
Gemuk ringan (>25.1- 27) & 2 & 10 \\
Gemuk berat (>27.1) & 4 & 20 \\
Riwayat Keluarga & & \\
Ada & 7 & 35 \\
Tidak Ada & 13 & 65 \\
Kunjungan Konseling & & \\
Pernah & 10 & 50 \\
Tidak Pernah & 10 & 50 \\
Lama Mnederita & & \\
1-3 Tahun & 15 & 75 \\
4-5 Tahun & 4 & 20 \\
6-8 Tahun & 1 & 5 \\
\hline
\end{tabular}

RSUD.dr.M.Yunus Bengkulu pada tahun 2017 yaitu sebanyak 1083 orang penderita diabetes melitus. total sampel dalam penelitian ini totalnya adalah 20 responden.

$$
\text { Pengumpulan data primer }
$$
diperoleh melalui pre-test dan post-test menggunakan kuesioner food recall $2 \times 24$ jam . Kuesioner pre-test dan posttest untuk mengukur asupan recall pasien selama 2x24 jam dalam seminggu. Sedangkan data skunder diperoleh dari data sistem pencatatan dan pelaporan jumlah kunjungan pasien Diabetes Melitus di RSUD dr. M.Yunus Bengkulu pada tahun 2017.

Analisis data Analisis data dilakukan analisis univariat dan bivariat. Analisis univariat digunakan untuk melihat gambaran frekuensi distribusi karakteristik responden,ratarata asupan zat gizi . Sedangkan Data bivariat menggunakan dua uji yaitu $u j i$ kolmogrov smirnov dan uji wilcoxon. Uji wilcoxon dilakukan untuk mengetahui ada atau tidaknya pengaruh sebelum dan setelah dilakukan konseling gizi terhadap kualitas diet pasien diabetes melitus. 


\section{HASIL PENELITIAN}

Berdasarkan Tabel 1 menurut kategori jenis kelamin sampel berjumlah 20 orang diantaranya 10 orang laki-laki dan 10 orang perempuan dengan persentase $50 \%$ berarti setengah dari responden. Berdasarkan kategori umur hampir sebagian dari responden umur 56-65 Tahun berjumlah 8 orang terdiagnosa diabetes melitus type 2 . Pada kategori pendidikan hampir sebagian dari responden pendidikan tertinggi adalah perguruan tinggi berjumlah 7 orang. Pada kategori pekerjaan hampir sebagian dari responden bekerja sebagai Ibu rumah tangga (IRT) berjumlah 7 orang.

Kategori IMT sebagian besar dari responden yang memiliki IMT normal berjumlah 11 orang yang terdiagnosa diabetes melitus. Pada kategori riwayat keluarga sebagian besar dari responden tidak memiliki riwayat keluarga berjumlah 13 orang. Pada kategori kunjungan konseling setengah dari responden pernah melakukan kunjungan konseling dan ada juga yang tidak pernah sama sekali kunjungan konseling secara rutin. Pada kategori lama menderita diabetes melitus sebagian besar responden lama menderita diabetes melitus 1-3 tahun sebanyak 15 orang

Berdasarkan Tabel 2 menunjukkan bahwa asupan energi sebelum diberikan konseling rata-rata asupan 913.20 dan meningkat menjadi 1187.74 sesudah konseling gizi dengan standar deviasi sebelum konseling 406.20 dan sesudah konseling 337.647. Pada asupan protein rata-rata sebelum diberikan konseling 41.72 meningkat menjadi 58.85 pada asupan protein sesudah konseling dengan standar deviasi asupan protein sebelum konseling 21.887 dan sesudah konseling

Tabel 2. Rerata Asupan Zat Gizi Sebelum Konseling Gizi Dan Sesudah Konseling Gizi Pada Pasien DM Tipe II Di RSUD dr. M. Yunus Bengkulu Tahun 2018

\begin{tabular}{llcccc}
\hline \multicolumn{2}{c}{ Variabel } & Mean & SD & Min & Max \\
\hline Asupan Energi & Sebelum & 913.20 & 406.20 & 457 & 2086 \\
& Sesudah & 1187.74 & 337.647 & 705 & 1890 \\
\hline Asupan protein & Sebelum & 41.72 & 21.887 & 16 & 104 \\
& Sesudah & 58.85 & 19.943 & 25 & 92 \\
\hline Asupan lemak & Sebelum & 28.71 & 15.049 & 9 & 66 \\
& Sesudah & 42.29 & 14.696 & 16 & 66 \\
\hline Asupan & Sebelum & 128.10 & 62.440 & 56 & 280 \\
Karbohidrat & Sesudah & 149.68 & 42.320 & 86 & 256 \\
\hline
\end{tabular}


gizi standar deviasi pada asupan protein 19.94. Asupan lemak didapatkan ratarata sebelum diberikan konseling 28.71 meningkat 42.29 sesudah konseling dan standar deviasi pada asupan lemak sebelum konseling 15.04 dan sesudah konseling 14.69.

Pada asupan karbohidrat sebelum diberikan konseling rata-rata yang didapatkan 128.10 meningkat 149.68 dengan standar deviasi sebelum diberikan konseling 62.440 dan sesudah konseling standar deviasi 42.32 .

\section{Analisis Bivariat}

Berdasarkan hasil analisis uji wilcoxon menunjukkan bahwa ada pengaruh skor HEI dari asupan sebelum dan sesudah di berikan konseling gizi pada pasien diabetes melitus type II di poli dalam RSUD dr. M. Yunus Bengkulu Tahun 2018, dengan rata-rata skor HEI sebelum 34.00 dan standar deviasi 8.974 dan rata-rata skor HEI setelah konseling 41.50 dengan standar deviasi 7.273 hal ini di tunjukkan dengan nilai $p$ value $0.006 \quad(<0.05)$ dengan selisih yang didapatkan rata-rata 7.5 dengan standar deviasi 1.70 .

\section{PEMBAHASAN}

Diabetes melitus merupakan penyakit kronik yang tidak dapat di sembuhkan. Diabetes melitus merupakan penyakit yang berhubungan dengan gaya hidup oleh karena itu berhasil tidak berhasilnya pengelolaan diabetes melitus tergantung pada diri sendiri. Ada empat pilar utama pengelolaan diabetes melitus adalah perencanaan makan, latihan jasmani, obat hipoglikemik, dan edukasi. (8)

Diet memiliki peranan penting dalam pencegahan hiperglikemia dan diabetes. Efidemiologi gizi adalah pola makan, pola makan yang buruk dan kualitas diet yang rendah berpotensi menimbulkan penyakit kronis terkait

Tabel 3. Perubahan Asupan Sebelum Dan Sesudah Skor HEI, Konseling Gizi Pasien Diabetes Melitus Type II

\begin{tabular}{ccccc}
\hline Variabel & Mean \pm SD & Min \pm Max & $\Delta \dot{\mathbf{X}} \pm$ SD & P-value \\
\hline Skor HEI & & & & \\
Sebelum & $34.00 \pm 8.974$ & $10 \pm 50$ & & \\
Sesudah & $41.50 \pm 7.273$ & $30 \pm 55$ & $7.5 \pm 1.70$ & $0.006^{*}$
\end{tabular}


obesitas.5 Kualitas diet ditentukan berdasarkan skor HEI yang diperoleh, skor HEI yang tinggi menunjukkan kualitas diet yang baik.

\section{Karakteristik Pasien Diabetes Melitus Di Poli Penyakit Dalam RSUD dr. M.Yunus Bengkulu Tahun 2018.}

Karakteristik individu contoh yang diteliti meliputi jenis kelamin, usia, status gizi, pendidikan, pekerjaan, kunjungan konseling dan riwayat penyakit DM. Berdasarkan tabel 4.1 sebagian besar prevalensi pada sampel berusia $45-55$ tahun (45\%) hal ini sesuai dengan penelitian yang mengatakan bahwa Diabetes melitus tipe 2 adalah tipe diabetes yang paling banyak ditemukan, yaitu 90-95\% dari seluruh pengidap DM dan sering terjadi pada usia diatas 45 tahun.9 Dan menurut Perkeni 2011 penderita DM tipe 2 banyak diderita pada usia tersebut yang merupakan kategori usia dewasa akhir.

Pada penelitian ini, karakteristik sampel berdasarkan jenis kelamin didapatkan mayoritas sama $50 \%$ perempuan dan $50 \%$ laki-laki dikarenakan sampel yang diambil 20 orang. Tingginya sampel hingga 50\% karena perempuan mempunyai kecendrungan untuk mengalami diabetes melitus dan diabetes melitus gestasional. Tingginya diabetes melitus dihubungkan dengan faktor kegemukan sebagai faktor pencetus diabetes melitus tipe 2.10

Karakterisitik sosial ekonomi keluarga contoh yang diteliti meliputi pekerjaan, tingkat pendidikan pasien. Faktor- faktor yang dapat mempengaruhi pencapaian peningkatan pengetahuan tentang diet diabetes melitus dalam penelitian ini adalah tingkat pendidikan.

\section{Ratae Asupan Zat Gizi Sebelum dan Sesudah Diberikan Konseling Gizi Pada Pasien DM Tipe II Di RSUD Dr. M. Yunus Bengkulu Tahun 2018}

Dari hasil recall yang didapat asupan karbohidrat pasien mengalami peningkatan karena bahan makanan yang sering dikonsumsi pasien adalah nasi, dan kue yang setiap harinya dikonsumsi dan sudah menjadi sumber makanan pokok negara Indonesia. Penderita DM harus memperhatikan takaran karbohidrat yang dikonsumsi, sebab lebih dari separuh kebutuhan energi diperoleh dari karbohidrat. Ada dua golongan karbohidrat kompleks dan karbohidrat sederhana dari sisi makanan penderita DM sebaiknya mengkonsumsi 
karbohidrat berserat seperti kacangkacangan, sayuran, buah segar.

Kebutuhan protein sebesar $10-$ $20 \%$ total asupan energi. Sumber protein yang baik adalah ikan, udang, cumi, daging tanpa lemak, ayam tanpa kulit, produk susu rendah lemak, kacang-kacangan, tahu dan tempe. Pada pasien dengan nefropati diabetik perlu penurunan asupan protein menjadi 0,8 $\mathrm{g} / \mathrm{kg}$ BB perhari atau $10 \%$ dari kebutuhan energi, dengan $65 \%$ diantaranya bernilai biologik tinggi.(11)

Komposisi yang dianjurkan : lemak jenuh $<7 \%$ kebutuhan kalori, lemak tidak jenuh ganda $<10 \%$, selebihnya dari lemak tidak jenuh tunggal. Bahan makanan yang perlu dibatasi adalah yang banyak mengandung lemak jenuh dan lemak trans antara lain: daging berlemak dan susu fullcream. Konsumsi kolesterol dianjurkan $\quad 200$ $\mathrm{mg} /$ hari.(11)

Karbohidrat yang dianjurkan sebesar $45-65 \%$ total asupan energi terutama karbohidrat yang berserat tinggi. Pembatasan karbohidrat total $<130$ g/hari tidak dianjurkan. Komposisi yang dianjurkan : lemak jenuh $<7 \%$ kebutuhan kalori, lemak tidak jenuh ganda $<10 \%$, selebihnya dari lemak tidak jenuh tunggal.
Kebutuhan protein sebesar $10-20 \%$ total asupan energi. Sumber protein yang baik adalah ikan, udang, cumi, daging tanpa lemak, ayam tanpa kulit, produk susu rendah lemak, kacangkacangan, tahu dan tempe.(11)

Pengaruh Konseling Gizi Terhadap Kualitas Diet Pada Pasien Diabetes Melitus Di Poli Penyakit Dalam RSUD dr. M.Yunus Bengkulu Tahun 2018.

Berdasarkan hasil analisis uji wilcoxon menunjukkan bahwa ada pengaruh skor HEI dari asupan sebelum dan sesudah di berikan konseling gizi pada pasien diabetes melitus type II di poli dalam RSUD dr. M. Yunus Bengkulu Tahun 2018, dengan rata-rata skor HEI sebelum 34.00 dan standar deviasi 8.974 dan rata-rata skor HEI setelah konseling 41.50 dengan standar deviasi 7.273 hal ini di tunjukkan dengan nilai $p$ value $0.006 \quad(<0.05)$ dengan selisih yang didapatkan rata-rata 7.5 dengan standar deviasi 1.70.

Terdapat pengaruh yang signifikan antara kualitas diet awal dan kualitas diet akhir pada kelompok konseling menggunakan media cakram. Hal ini menunjukkan bahwa penggunaan media cakram dalam konseling gizi dapat meningkatkan kualitas diet pada pasien diabetes melitus tipe 2.Jika dilihat dari 
perbandingan kualitas diet awal dan kualitas diet akhir hasil ini menunjukkan bahwa ada pengaruh positif dan signifikan dari pendidikan kesehatan yang menggunakan media cakram.

Menurut hasil penelitian tentang konseling gizi mempengaruhi kualitas diet pasien diabetes melitus tipe 2 di RSUP dr.Sardjito Yogyakarta didapatkan hasil dari penelitian tersebut bahwa perubahan kualitas diet kelompok control berbeda signifikan dengan perubahan kualitas diet pada kelompok perlakuan. Konseling gizi individu dan kelompok terarah terbukti memperbaiki kualitas diet pada pasien diabetes melitus.(5)

Media cakram tersebut digunakan untuk mempermudah dalam proses konseling, setelah dilakukan konseling diketahui terdapat peningkatan pada skor kualitas diet. Konseling gizi dapat meningkatkan pengetahuan pasien, dimana peningkatan pengetahuan dapat merubah perilaku pasien untuk mengkonsumsi makanan sesuai anjuran agar dapat menurunkan kadar gula darah. Sejalan dengan penelitian ini mengatakan bahwa dari uji perbedaan kualitas diet awal dan kualitas diet akhir adalah p-value $(0,000)<0,005$ sehingga dapat dikatakan ada perbedaan yang signifikan antara kualitas diet awal dengan kualitas diet akhir pada kelompok konseling menggunakan booklet. (12)

\section{SIMPULAN}

Karakteristik pasien pada kelompok cakram di RSUD dr. M. Yunus Bengkulu dengan sampel 20 responden sebagian besar berjenis kelamin lakilaki dan perempuan, berusia 56-65 tahun, berpendidikan tinggi adalah perguruan tinggi, dengan pekerjaan hampir sebagian ibu rumah tangga,sebagian besar memiliki IMT normal, telah mendapatkan konseling gizi sebelum dilakukan penelitian, sebagian besar lama menderita diabetes melitus 1-3 tahun.

Rata-rata Asupan zat gizi sebelum dan sesudah diberikan konseling gizi pada pasien diabetes melitus terjadi peningkatan asupan energi, protein, lemak, karbohidrata sebelum dan sesudah diberikan konseling gizi.

Hasil uji statistik wicoxon perubahan sebelum dan sesudah konseling gizi didapatkan p-value 0.006 $(<0.05)$ yang berarti ada pengaruh konseling gizi terhadap kualitas diet pasien diasbetes melitus sebelum dan sesudah diberikan konseling. 


\section{SARAN}

Saran dari penelitian ini diperlukan observasi lebih lanjut mengenai efek konseling gizi terhadap perubahan kualitas diet pasien diabetes melitus dalam jangka waktu yang lebih panjang dan jumlah sampel yang lebih besar.

\section{UCAPAN TERIMA KASIH}

Penulis mengucapkan terima kasih kepada pembimbing dan penguji yang telah memberikan saran yang bersifat membangun sehingga skripsi ini dapat diselesaikan.

\section{DAFTAR PUSTAKA}

1. World Health Organization. Diabetes Fakta dan Angka. In Diabetes di Dunia. 2016.

2. International Diabetes Federation. IDF Diabetes Atlas Seventh Edition $2015 . \quad$ [www.diabetesatlas.org. Diakses pada tanggal 21 Mei 2016].

3. Badan Penelitian dan Pengembangan Kesehatan. Riset Kesehatan Dasar (RISKESDAS) 2013. Laporan Nasional P2013, 1384. https://doi.org/1 Desember 2013

4. Persatuan Ahli Gizi Indonesia PERSAGI. Penuntun Konseling Gizi. Jakarta:Penerbit PT.Abadi. 2010.

5. Widya, S., Budi, L., \& Purba, M. Konseling gizi mempengaruhi kualitas diet pasien diabetes mellitus tipe 2 di RSUP Dr.Sardjito Yogyakarta. Jurnal Gizi Dan Dietetik Indonesia, 3(1), 31-40. 2015.

6. Sri Mulyani Nunung. Pengaruh Konsultasi Gizi Terhadap Asupan Karbohidrat dan Kadar Gula Darah
Pasien Diabetes Mellitus Tipe II di Poliklinik Endokrin Rumah Sakit Umum Daerah dr. Zainoel Abidin Banda Aceh. Jurnal Kesehatan Ilmiah Nasuwakes, 8, 144-151. 2015.

7. Putra, F. D., \& Mahmudiono, T. Hubungan Tingkat Konsumsi Karbohidrat, Lemak, dan Dietary Fiber Dengan Kadar Gula Darah Pada Penderita Diabetes. Media Gizi Indonesia, 2(9), 1528-1538. 2012.

8. Wahyu.paramita. A. Perbedaan Pengetahuan Gizi, Pola Makan, dan Kontrol Glukosa Darah Pada Anggota Organisasi Penyandang Diabetes Melitus dan Non Anggota. Artikel Penelitian Ilmu Gizi Fakultas Kedokteran.Universitas Diponegoro. 2013.

9. Soegondo, S.,Obesitas. Dalam : Aru W, dkk, editors, Ilmu Penyakit Dalam, Jilid III, Edisi keempat. Jakarta : Penerbit Fakultas Kedokteran Universitas Indonesia. 2007.

10. Levine JP,. Type 2 Diabetes among Women: Clinical Consideration for Pharmalogical Management to Achieve Glicemic Control and Reduce Cardiovaskular Risk . Journal of Woman's Health. Vol \&. No 2.2008.

11. PERKENI. Konsensus Pengendalian dan Pencegahan Diabetes Melitus Tipe 2 di Indonesia 2015. Perkeni. https://doi.org/10.1017/ CBO9781107415324. 004. 2015.

12. Hermawan H,Weni Kurdati, N. T. Efektivitas Konseling Gizi Menggunakan Media Booklet Dibandingkan Dengan Leaflet Terhadap Kulaitas Diet Pasien Diabetes Mellitus Tipe 2 Di puskesmas Gambing II. 2017. 